\title{
Lexis
}

Journal in English Lexicology

$7 \mid 2012$

Euphemism as a Word-Formation Process

\section{Lexical Creation and Euphemism: Regarding the Distinction Denominative or Referential Neology vs. Stylistic or Expressive Neology}

\section{María Tadea Díaz Hormingo}

\section{(2) OpenEdition \\ Journals}

Electronic version

URL: http://journals.openedition.org/lexis/371

DOI: 10.4000/lexis.371

ISSN: 1951-6215

Publisher

Université Jean Moulin - Lyon 3

\section{Electronic reference}

María Tadea Díaz Hormingo, « Lexical Creation and Euphemism: Regarding the Distinction Denominative or Referential Neology vs. Stylistic or Expressive Neology », Lexis [Online], 7 | 2012, Online since 25 June 2012, connection on 19 April 2019. URL : http://journals.openedition.org/lexis/371 ; DOI : 10.4000/lexis.371

\section{(c) (i) (9)}

Lexis is licensed under a Creative Commons Attribution-NonCommercial-NoDerivatives 4.0 International License. 


\title{
Lexical Creation and Euphemism: Regarding the Distinction Denominative or Referential Neology vs. Stylistic or Expressive Neology*
}

\author{
María Tadea Díaz Hormingo ${ }^{1}$
}

\begin{abstract}
The commonly established general typology of neology and/or neologism includes the distinction between denominative or referential and stylistic or expressive neology, according to the function or aim of the lexical creation in question. The term denominative or referential neology is used to refer to the creation of new lexical units to denominate new concepts, objects or realities, whereas stylistic or expressive neology refers to the use of lexical creation to introduce different subjective nuances or new, expressive or original forms in communication. However, the distinction between denominative or referential neology and stylistic or expressive neology is insufficient, since in no way does it cover the wide range of linguistic and extralinguistic motivations underlying the new lexical units that may be called euphemistic. In this paper, we will endeavour to prove this assertion, at the same time accounting for some of the motivations upon which euphemistic creations are based.
\end{abstract}

Key words: neology - neologism - euphemism - euphemistic substitute - motivation acceptability - lexicalisation

\footnotetext{
* This article has been included in the lines of research on "Communication linguistics" and "Lexical creation and formation" carried out in the framework of projects by the group belonging to the Andalusian Research Plan Semaínein [ref.: HUM 147], subsidised by the Andalusian Regional Government and belonging to the area of General Linguistics in the Department of Philology of the University of Cádiz. I would like to thank especially Mary Joplin for her translation of this paper.

1 University of Cádiz: tadea.diaz@uca.es
} 


\section{TI e linguistic study of lexical creation or neology/ Lexical creation from a linguistic viewpoint}

The study of lexical creation or neology ${ }^{2}$ from a strictly linguistic point of view must refer to the description of the linguistic processes of creation of new lexical units or neologisms ${ }^{3}$ and the analysis of the resulting neological products. The theoretical and applied study of lexical innovations is another of its aims. Therefore, it must attend to the criteria of recognition, diffusion and acceptability of neologisms and the consequences of these new lexical units for the system of the language. Of all the aspects mentioned, in this article we will pay special attention to certain questions which have to do with the acceptability of neologisms.

In this respect, it must be made clear that the acceptability of new lexical units depends to a great extent, although not exclusively, on the level of social esteem obtained by the neologism. The level of acceptability is closely related to the awareness of the need for the designation of a concept, object or reality. For this reason, the question of the acceptability of a lexical creation is related to the common boundary between lexical units created to designate new concepts, objects or realities denominative or referential neologisms- and those created to introduce subjective nuances or new or original expressive forms in communication -stylistic or expressive neologisms-. The former generally have a wider diffusion and acceptability than the latter group, but, in fact, we believe that nuances and other subdivisions could be created for both groups. In any case, this distinction is just one of those that are usually taken into account for the classification of new lexical units.

\section{A typology of neology}

In fact, the general typology which is commonly established for neology and/or neologisms includes the boundaries between a) lexical neology in common language vs. lexical neology in specialised language; b) spontaneous neology vs. planned neology; c) denominative or referential neology vs. stylistic or expressive neology, and d) formal

\footnotetext{
2 As we pointed out in Díaz Hormigo [2007: 33-35], in general, neology is understood to refer to 1) the process of creation of new lexical units, and 2) the discipline that studies everything related to the creation of new lexical units .Cf. the entry of neology in the DRAE 2003, in which it is advertised as "Artículo nuevo. Avance de la vigésima tercera edición" [New article. Advance of the twenty-third edition], which includes for this term the acceptions '1. f. Ling. Proceso de formación de neologismos' [Ling. The process of formation of neologisms] and '2. f. Ling. Estudio de los neologismos' [Ling. The study of neologisms].

3 Neologism is the result of the lexical creation process, that is, its product, the new lexical unit. The criteria and parameters used by neologists to establish the neological character or neologicity of a lexical unit [Cabré 1993: 445] are diachrony, lexicography, systematic instability and psychology. A lexical unit is inferred to be a neologism because it has appeared recently; consequently it does not appear in general language dictionaries; presumably it is recognised as new by speakers, and, further, it may show signs of linguistic instability since it is not consolidated in the language. These new lexical units, which are products of neological creation processes, may be novel both in their signifiant and signifié, or only in their signifiant, or only in their signifié, or have been recently borrowed from another language. However, for a revision of the concepts of neology and neologism, see Díaz Hormigo [2008: 9-13, 2010] Examples of neologisms in French, Spanish, Portuguese, Romanian, Catalan and Galician can be found in the neology data base of the Observatory of Neology of the Institute of Applied Linguistics of the University Pompeu Fabra) (http://www.iula.upf.edu, http://obneo.iula.upf.edu/bneorom/index.php).
} 
and ordinary neology, neology of form or of form and sense vs. semantic or sense neology. These distinctions are based on at least four different criteria.

\subsection{Lexical neology of common language vs. lexical neology of specialised language}

Thus, as Cabré [1993: 446-448] and Cabré et alii [2002: 161-164] point out, Rondeau's proposed distinction [1984] between lexical neology of common language (general neology or neology itself) and lexical neology of specialised language (specialised neology, terminological neology or neonymy) comes from examining the relevance of neologisms to the system of the language and their area of use. Lexical neologisms of common language are characterized mainly by their spontaneity and not by the necessary motivation of their creation, their frivolity, their sometimes ephemeral nature, their possible synonymy with other lexical units of the same language, and, similarly, their stylistic value. With regard to terminological neologisms or neonyms, these, like the terms themselves, respond above all to a necessity of creation in order to designate a concept, their univocity and monoreferentiality, absence of synonymy, neutrality in the expression of connotations and affective values, unambiguity, stability of duration and relevance to a single area of speciality.

\subsection{Spontaneous neology vs. planned neology}

From the above, we can infer a second boundary in the area of neology. Thus, following the criterion of examining its origin and the nature of the creative process, neology can be spontaneous or planned. For Cabré et alii [2002:161-162] spontaneous neologisms arise from an individual act that takes place in order to name a new concept or to introduce a stylistic or expressive variation in the system of denomination. Therefore, spontaneous neology can be the result of an unconscious process; the speaker can create a new lexical unit without realizing that it does not exist, and which, for this reason, does not appear in language dictionaries. However, it may also be the result of a conscious action, as a new lexical unit may be created to attract the receiver's attention or for the sake of originality. For its part, planned neology may be individual, or, more usually, institutional. In any case, planned neologisms arise from the social and political necessity to designate a new concept, replace a designation considered inappropriate or simplify several variations with a single means of reference.

\subsection{Denominative or referential neology vs. stylistic or expressive neology}

So, according to the criterion of its function or aim, neology can be, as we have already indicated in section 1., either denominative or referential or stylistic or expressive. The neologisms which arise for the denomination of new concepts, objects and realities are called denominative, whereas those which arise to introduce subjective nuances or new expressive and original forms in communication are known as stylistic or expressive. 


\subsection{Formal and ordinary neology, neology of form or of form and sense vs. semantic or sense neology}

However, it is always possible to distinguish between those which appear in the form of a signifiant notyet registered in the language and those which do so in the form of an existing signifiant. For this reason, depending on the resource used for the new lexical creation, we can distinguish between formal neology, ordinary neology, neology of form, neology of form and sense, and semantic or sense neology. The former group consists of the creation of new signifiants or new signifiants and signifiés. This explains the proximity of external borrowings to this type ${ }^{4}$. Semantic or sense neology is based on the appearance of new meanings or new acceptions for existing signifiants.

Likewise, with respect to the types of formal neology, ordinary neology, neology of form or of form and sense and semantic or sense neology, a classification of diverse lexical creation procedures existing in the language is generally made. Regarding this, the sum of all the neological creation mechanisms cited by various authors (Matoré [1952]; Deroy [1971]; Sauvageut [1971]; Rey [1976]; Pottier-Navarro [1979]; Fernández-Sevilla [1982]; Guerrero Ramos [1995]) allows us to include in formal neology resources of creation ex-nihilo; by onomatopoeia; by prefixation, suffixation, prefixation and suffixation, subtraction, lexical or orthographical composition, learned composition, syntagmatic composition or syntagmation -sometimes included in semantic neology-; by abbreviation, acronymy or initials, and unadapted borrowings or adapted ones, and calques. In the case of semantic neology, the neological creation mechanisms mentioned are categorical conversion (neology by conversion) or subcategorial (syntactic neology) and by the lexicalisation of a flexive form, metaphorical, antonomasic, metonymic and synecdochic creation, and by ellipsis originating from lexical combination and, as such, the cause of semantic change ${ }^{5}$.

\section{TI e classification of new eupI emistic lexical creations}

Indeed, it would appear that it is not difficult to classify new lexical creations that are euphemistic substitutes ${ }^{6}$ within the types of a) neology of common language vs. neology of specialised language, b) spontaneous neology vs. planned neology and c) formal neology vs. semantic neology. As we will discuss later, lexical units that act as euphemistic uses or substitutes are, in general, common language creations, of a spontaneous nature and based on a change or alteration in form and/or semantics of an existing lexical unit.

\footnotetext{
4 Nonetheless, authors such as Auger and Rousseau [1977] consider this borrowing neology separately.

5 But, as we pointed out [Díaz Hormigo 2007], researchers on neology do not include among the creation processes of these new lexical units the so-called expressive lexical creations, or those arising from popular etymology or word blending or word play, which are seen in literary or common language creations. Neither do they distinguish calques which are the literal translation of a foreign expression used to designate the same concept -formal neologisms- and those which are based on the addition of a new meaning to a word that is formally analogous to another foreign word with the same meaning -semantic neologisms.

6 The concepts of euphemism and euphemistic substitute have frequently been identified. Here we wish to use the distinction between the two concepts proposed in Casas Gómez [2000: 79], [2005: 272-273] and [2005: 273-275]. Thus, euphemism refers to the linguistic process itself of substitution or the linguistic manifestation of the term to be avoided or of the forbidden reality. The word or expression that replaces the forbidden term is the euphemistic substitute.
} 
However, the demarcation of denominative or referential neology vs. stylistic or expressive neology is insufficient for the analysis of new lexical units which could be considered as euphemistic. So, for an exact analysis, among other things, we would have to specify the wide range of linguistic motivations which may be underlying in stylistic or expressive neologisms. Euphemistic creations are generally classified in this type of neology. The social esteem acquired and by extension, their diffusion and acceptability will, in our opinion, depend to a great extent on the forbidden area or reality and on the extralinguistic motivation that brings about the substitution of one lexical unit by another used euphemistically.

In order to clarify these ideas, and before giving examples, it would seem useful to mention the conclusions drawn from the examination of different concepts and descriptions of the euphemistic phenomenon.

\section{Descriptions of tI e eupI emistic pI enomenon}

Indeed, the revision of the definitions of the lexical substitution process known as euphemism that have been formulated up to the present ${ }^{7}$ enable us to gather information about 1) the real causes or extralinguistic motivations underlying euphemistic substitutions, according to scholars of the euphemistic phenomenon; 2) the peculiarities of a certain designation (word or expression) which bring about its substitution or replacement by a different one; 3) the aims of these euphemistic substitutes; that is, the intention behind them, the reason for which they take place. In relation to the aforementioned distinction between denominative or referential neology vs. stylistic or expressive neology, Armenta Moreno [2009: 23] considers euphemism and dysphemism as "dos variantes estilísticas que el hablante elige en función de su intención comunicativa, esto es, suavizar o intensificar el tabú" [two stylistic variants chosen by the speaker depending on his communicative intention, that is, to attenuate or intensify the taboo]. About this attenuation and intensification of the taboo conceptual traits in relation to euphemism and dysphemism, see Crespo Fernández [2007: 43-44], and 4) the enumeration of linguistic mechanisms and resources on which potential euphemistic substitutes are based, and which can, in turn, respond to a specific type of linguistic motivation ${ }^{8}$.

\subsection{Extra-linguistic causes}

Few authors, in their respective definitions of euphemism, allude specifically to the extralinguistic causes motivating euphemistic substitutions, and those that do so only mention that euphemistic substitution occurs because there is a word, idiom or expression that is avoided for reasons of religious fear, moral scruples or courtesy [Hatzfeld 1924: 107], or for an underlying psychological motive (dread, courtesy and decency or decorum) [Ullmann 1976: 231], or because it designates something which causes fear [Kany 1960: V], or simply because of social pressure [Alcaraz Varó and Martínez Linares 1997: 219-220]. Therefore, religious fear, moral scruples, courtesy,

\footnotetext{
7 In this case we took as a reference the complete collection of extra-linguistic and linguistic definitions of the euphemism given by Casas Gómez [2009, 2011].

8 For an exposition and critical exegesis of the different types and classes of existing linguistic motivations, in relation to the different procedures of creation and lexical formation, see Penadés Martínez and Díaz Hormigo [2008].
} 
dread, decency, decorum and social pressure are considered by these authors to be the extralinguistic motivations that give rise to linguistic substitutions ${ }^{9}$.

However, among the consigned definitions of the euphemistic phenomenon, we can also distinguish those in which the causes of the euphemistic substitution are not clear, but it is clear that such causes exist. In this respect, it is said vaguely that the euphemistic use of a lexical unit is chosen "por alguna razón" [for some reason] [Seco 2002: 8], "por algun motivo" [for some cause] [Moliner 1998: 1239-1240], "por alguna que otra razón" [for one reason or another] [Fernández Ulloa 1998: 40], "por razones diversas" [for various reasons] [Lechado García 2000: 14], "pour une raison quelconque" [for whatever reason] [Nyrop 1913: 257], or simply because "nuestra competencia lingüística así nos lo sugiere" [our linguistic competence suggests it] [Edeso Natalías 2009: 147 and 150], without mentioning anything else to justify this assertion about our linguistic competence.

\subsection{CI aracteristics of substituted words and expressions}

With regard to the peculiarities that a particular designation (word or expression) may present in order to be substituted or replaced, we must highlight the definitions of euphemism in which the reason for the substitution is found in the characteristics of the designation itself. There are others which consider that the designated area, that is, the realities referred to by these words and expressions, determines that these denominations be replaced.

Thus, it is necessary to substitute words or expressions considered to be annoying or inappropriate [Cerdà 1986, s.v. eufemismo], those which are considered taboo, non grata, in bad taste, offensive, unpleasant, hard, coarse, violent, rude, forbidden, to o frank, badly considered, with excessive negative connotations, inappropriate, less appropriate or which we prefer not to enunciate [Hatzfeld 1924: 107; Howard 1986: 101; Allan and Burridge 1991: 11; Diccionario ideológico de la lengua española [Thesaurus of Spanish] 1995: 1154; Diccionario para la enseñanza de la lengua española [Dictionary for the teaching of Spanish language] 1995: 494; Richards, Platt and Platt 1997: 158; Fernández Ulloa 1998: 40; Seco, Andrés and Ramos 1999: 2043; Lechado García 2000: 14; Battaner Arias 2001: 763; Diccionario de uso del español de América y España [Dictionary of use of Spanish America and Spain] 2002: 814; Maldonado González 2002, s.v. eufemismo; Seco 2002: 8; DRAE 2003, s.v. eufemismo; Gómez Sánchez 2004: 45; Allan and Burridge 2006: 32]. Likewise, we must substitute the word which designates something unpleasant, offensive or frightening [Kany 1960: V] or that is annoying, dirty, inopportune or forbidden by taboo [Moreno Fernández 1998: 202], as well as the expression of certain facts or ideas, whose crudeness could offend [Lázaro Carreter 1974: 177; Dubois et alii 1979: 262; Cardona 1991: 106].

\subsection{Aims}

In the same way, from the aforementioned euphemistic definitions we can infer that the aim of euphemistic substitutions is: to obtain a word, phrase, expression, manifestation or denotation that is gentler, ambiguous, more pleasant, inoffensive, or less offensive, less unpleasant, decorous, neutral, tactful, veiled, more appropriate

\footnotetext{
9 Nonetheless, we could mention other motives, also governed by psychological criteria, to which many researchers of the phenomenon allude, such as superstition, religious beliefs, education, respect, puffery, the desire to please, etc, but these are not enumerated in the definitions examined.
} 
[Lázaro Carreter 1974: 177; Richards, Platt and Platt 1997: 158; Howard 1986: 101; Warren 1992: 135; Diccionario SALAMANCA de la lengua española [Spanish Language Dictionary SALAMANCA] 1996: 685; Battaner Arias 2001: 763; Diccionario de uso del español de América y España [Dictionary of use of Spanish America and Spain] 2002: 814; Maldonado González 2002, s.v. eufemismo; DRAE 2003, s.v. eufemismo; Gómez Sánchez 2004: 45; Álvarez 2005: 20]; express something in an attenuated or softened way, or with decorum [Dubois et alii 1979: 262; Diccionario ideológico de la lengua española [Thesaurus of Spanish] 1995: 494]; mask, dissemble, attenuate the meaning or signification of a word or expression [Lewandowski 1982: 128; Cerdà 1986, s.v. eufemismo]; designate a matter that is unpleasant, offensive or frightening with an indirect and softer term [Kany 1960: V]; break a link between unpleasant, annoying and inappropriate situations and things and their denominations [Cardona 1991: 106; Crespo Fernández 2007: 82-83]; flee from taboo [Crespo Fernández 2007: 82-83]; avoid the name of a certain reality [Seco 2002: 8]; avoid that which is forbidden, annoying, unpleasant, offensive, dirty [Moreno Fernández 1998: 202]; clean up some areas of life to make them more presentable [Wardhaugh 1986: 237]; improve the negativity of a (subjectively) taboo reality [Horak 2010: 62]; avoid the loss of prestige [Allan and Burridge 1991: 11; Allan and Burridge 2006: 32]; respect the right of the hearer not to be offended or annoyed [Alcaraz Varó and Martínez Linares 1997: 219-220] or disguise an unpleasant truth, veil an insult or mitigate an indecency [Kany 1960: V]. But the definitions of euphemism proposed by these scholars are not usually restricted to just one function.

\subsection{Linguistic resources}

Finally, we will refer to the exclusively linguistic resources or mechanisms on which euphemistic substitutes are based. In this respect, there are definitions of euphemism which allude to possible modifications of the form and the semantic content of the substituted units [Montero 1981: 26; Uría Varela 1997: 6; Casas Gómez 2009: 738] ${ }^{10}$. In other definitions [Martín Fernández 1994: 337; Chamizo Domínguez and Sánchez Benedito 2000: 37] only the semantic change and the figurative use of a lexical unit acting as a euphemistic substitute are mentioned ${ }^{11}$. And in other cases allusion is made to the substitution of the offensive word or expression by another, periphrastic one [Howard 1986: 101] or by a circumlocution [Lewandowski 1982: 128]. Nonetheless, Allan and Burridge [1991, 2006] indicate other, different linguistic strategies for the formation of euphemisms, which also include different formation processes.

In any case, although there are some exceptions [Montero 1981: 26; Casas Gómez 1986a: 35-36], in the definitions examined euphemistic substitutes are not seen as

\footnotetext{
10 It is specified [Uría Varela 1997; Casas Gómez 2009: 738] that phonetic alteration, modulation, lexical substitution, composition, morphological inversion, syntagmatic grouping and composition and textual description may all be used.

11 In fact, as in the studies referred to in this section, in most approaches to the linguistic phenomenon of euphemism it is not specified that the euphemistic substitute can consist of a creative resource other than semantic change. In some cases [Konrad 1958: 118; Casas Gómez 1993: 76-77; Chamizo Domínguez 1998, 2000: 101-133, 2005; Crespo Fernández 2007: 95-103] it is even emphasised that the metaphor is the most widespread and most used mechanism in euphemistic formation. In this respect, see the studies on the functional dimensions of the metaphor in the euphemistic process cited in Casas Gómez [1993: $77 \mathrm{n}$. 12]. However, it is only fair to highlight what is probably the most complete and all-embracing classification of the linguistic mechanisms that generate euphemistic and dysphemistic substitution, which is that of Casas Gómez [1986a: 97-251].
} 
resources of lexical creation, that is, of sources of enrichment of the lexical flow of the language. Nonetheless, it is evident that, in the same way as other lexical creations and neologisms, the diffusion and acceptability of euphemistic lexical units can lead to their lexicalisation and their forming part of the system of the language.

\section{EupI emistic substitutes tI at are motivated for tI e speaker but not for tI e I earer}

In this respect, it seems to be the mass media that demonstrate the vitality of a language and the changes, innovations and new additions to its vocabulary. Likewise, regarding the subject under discussion, the media serve to show, among many other aspects, that the creation of new lexical units or neologisms is one of the most fertile linguistic resources in order to mask reality. We can observe, for example, the tendency to distort the expression of events that have an immediate negative effect on daily life, in spite of the fact that it is not really 'forbidden' to talk about them. This tendency to camouflage events that have a negative impact on public opinion can be observed especially, although not exclusively, in political speech in the media by leaders of local, regional or national government. In preparing their speeches, it is clear that politicians or other public figures with social responsibility have the idea that certain realities are proscribed or forbidden, when in fact this is not so. Their supposed conceptual interdiction of certain domains and topics leads them to avoid using some existing forms and expressions of the language, giving rise to a euphemistic process. Certain words are passed over and replaced by linguistic expressions with underlying linguistic mechanisms. However, those who hear the speech might not consider it justified to treat these domains or subject areas as forbidden, and nor might they understand that the interdiction has a positive motivation.

In fact, certain events that have taken place have given rise to a political discourse that is full of new euphemistic lexical units, which have been created and used with the only aim, or political need, of trying to hide or show differently that which they do not wish to be known. With regard to this, the present economic crisis, the first Gulf war (1991), the sinking of the tanker Prestige (2002), the Iraq war (2003) or certain terrorist attacks have given rise to appearances in the media by public figures having social responsibility coining lexical units such as economic deceleration for crisis, negative growth for decreased productivity, recession for long-lasting serious economic situation, redundancy for mass sackings, price adjustment or revision for price rises, creditors meeting for temporary receivership, allied attack for war, collateral damage for civilian casualties, humanitarian aid for logistical support or military support, as well as diseconomy, restructuring process, military intervention, friendly fire, commando, armed struggle, armed wing, ceasefire, etc. These lexical units are examples of vocabulary created and used by politicians, but also by the armed forces, businessmen, economists, etc. with the sole aim of embellishing, deforming, or blurring the reality that they wish to hide. The economic crisis, military intervention in wars, ecological disasters, terrorist attacks, etc. have become interdictive fields for political, civilian and military leaders. However, for the rest of society, there are no motives due to external, psychological or social pressure which justify the prohibition of these areas and topics that are presented as forbidden conceptual categories. All this has an impact on the diffusion and acceptability of these euphemistic substitutes. 


\subsection{Classification}

Indeed, the analysis of these euphemistic lexical creations according to the general typology of neology and/or neologisms, described in section 2. of this article reveals that the cited examples are lexical creations of common language, spontaneous, ephemeral and sporadic, as they are related to the immediate context ${ }^{12}$. They have co-reference or 'quasi-synonymous'13 concurrence with other lexical units of the same language. Therefore, they do not designate a new concept, but they introduce a stylistic or expressive variant in the system of denomination. Hence, they can be called stylistic or expressive lexical creations. Likewise, these lexical creations arise from a conscious process, as a new unit is created in order to avoid calling things by their name, and so distracts the receiver's attention. The fact that they contribute to introducing subjective or new expressive forms of communication, and do not designate new concepts, objects or realities, as well as being referentially identified with other sufficiently general terms, leads to their being considered as unnecessary lexical creations or neologisms, although in some cases they can be exceptionally expressive creations.

\subsection{Aims}

Likewise, if we refer to the conclusions expressed in section 4., obtained from the examination of different conceptions and descriptions of the euphemistic phenomenon, it is clear that the abovementioned euphemistic substitutes are used to avoid the name of a certain reality, which is unpleasant. The designation has too many negative connotations and so it is replaced by another, considered by the speaker to be gentle, appropriate, veiled, tactful, etc. However, none of those mentioned (religious fear, moral scruples, courtesy, dread, decency, decorum and social pressure) seem to be the extralinguistic motive that gives rise to this type of euphemistic substitution that avoids calling things by their name. The cited euphemistic substitutes seek to disguise, hide, mask and distort reality as well as manipulating public opinion. Not doing this, or not doing it successfully, would have a negative effect for the spokesperson and would result in the loss of power and prestige, connected to face concerns (see Allan and Burridge [1991, 2006]).

\section{EupI emistic substitutes tI at are motivated for botI tI e speaker and tI e I earer}

Let us now compare the characteristics of these euphemistic lexical units given as examples with those of other euphemistic substitutes and uses which respond to a different extralinguistic motivation. These examples are creations of what is now called politically correct language: a long and painful illness for cancer, Maghrebi for Moor, AfroAmerican for black, visually impaired for blind, mentally disabled for retarded, senior citizen for old age, voluntary death for suicide. Such politically correct manifestations are euphemistic variants which are used in certain forbidden domains in the sociopolitical

\footnotetext{
12 The unstable, ephemeral, temporary and relative character of euphemistic substitutes is commented on by Casas Gómez [1986a: 40-48, 1986b: 40, 1993:78-80, 2005: 274-275].

13 The analogies and differences between the linguistic phenomenon of euphemism and synonymy have been examined in detail in Casas Gómez [1995, 2000: 81-82, 2005: 277-278], and with regard to Senabre's [1971] consideration of the euphemism as lexical synchretism in Casas Gómez [1993].
} 
sphere, such as illnesses, disabilities, physical defects, the effects of age, racism, xenophobia, sex, etc.

\subsection{Classification}

So, we can see that these, like the other examples cited and analysed in section 5., are lexical creations or neologisms of common language, which have also been propagated by the mass media. And since they are co-referential and 'quasi-synonymically' concurrent with other lexical units of the same language, they can be considered as stylistic or expressive neologisms. Indeed, they do not designate a new concept, object or reality but, rather, they are stylistic variants introducing new expressive forms in communication. Therefore, contrary to the designative need that is closer, but not exclusive to, terminological creation, in these creations, as with those in section 5., we can observe stylistic subjectivity. Hence, like the previous ones, these creations can be dubbed unnecessary.

\subsection{Aims}

From the standpoint of extra-linguistic motivation, the authors have mentioned courtesy, decorum and social pressure as causes of euphemistic substitution. An annoying, inopportune or less appropriate word or expression, suggesting something pejorative or unpleasant for the hearer, is replaced by another that is more pleasant, gentler and less offensive.

\section{TI e level of social esteem of eupI emistic substitutes}

But, in spite of the fact that in sections 5. and 6. we have mentioned euphemistic substitutes that are stylistic or expressive neologisms, the level of social esteem given to the two groups is very different. This different consideration can be observed equally in specialised or terminological neologisms or neonyms, given the awareness of the necessity of their creation in order to designate a new concept or replace an unsuitable denomination. It is also clear for so-called denominative or referential neologisms, which are created spontaneously or planned to designate new concepts, objects or realities. However, the level of social esteem of stylistic and expressive neologisms created as euphemistic substitutes is also different, however strong the perception that they are lexical uses arising from the search for connotations.

Indeed, unlike those mentioned in section 6., the lexical substitutes in section 5. are the result of distorting the facts and reality. The lexicon has been manipulated, with the object of not calling realities by their name. The euphemistic substitutes in section 6 . are received positively because they seek to avoid offending ethnic, cultural or religious groups. On the other hand, the receiver has a negative perception of the euphemistic substitutes in 5 . because he is conscious of the extra-linguistic motivations underlying them and of the desired effect of these euphemistic uses and substitutions. In these cases, the euphemistic substitutes are not seen as a way of increasing the lexical flow in a positive sense, but rather as resources for the perversion of the language, a perversion that avoids calling things by their name. This has a negative effect on the social esteem given to the euphemistic substitutes in section 5. as compared to 6., and consequently, on their diffusion and level of acceptability. 


\section{Conclusions}

Therefore, we can conclude that the acceptability of lexical creation consisting of a euphemistic substitute depends both on the forbidden field or reality and on the extralinguistic motivation that gives rise to the said euphemistic substitution. Moreover, neology, since it undertakes to analyse the conditions of creation, diffusion and acceptability of new lexical units, must examine the extra-linguistic motivations that propitiate the use of euphemistic substitutions which have such marked repercussions for their social esteem and diffusion. This is an aspect that will undoubtedly affect the lexicalisation of the neologism and its entry in the system of the language, as well as in the different connotations that it may contribute should it acquire a certain stability in the linguistic norm.

\section{BibliograpI y}

Alcaraz Varó Enrique and Martínez Linares María Antonia, Diccionario de lingüística moderna, Barcelona: Ariel, 1997.

Allan Keith and BurRIDGE Kate, Euphemism and Dysphemism. Language Used as Shield and Weapon, New York-Oxford: Oxford University Press, 1991.

Allan Keith and BURRIDGE Kate, Forbidden Words. Taboo and the Censoring of Language, Cambridge-New York: Cambridge University Press, 2006.

Álvarez A. I., Hablar en español, Oviedo: Nobel, 2005.

Armenta Moreno Luisa María, "La interdicción lingüística en textos legales educativos (1986-2006)”, Pragmalingüística, Vol. 17, 2009: 8-27.

AugER Pierre and RouSSEAu Louis-Jean, Metodología de la investigación terminológica, Málaga: Universidad de Málaga, 2003 [1977].

BatTaner ARIas M. Paz, Lema. Diccionario de la lengua española. VOX, Barcelona: Spes Editorial, 2001.

CABRÉ María Teresa, La terminología. Teoría, metodología, aplicaciones, Barcelona: Editorial Antártida/Empúries, 1993.

CABré María Teresa et alii, "Evaluación de la vitalidad de una lengua a través de la neología: a propósito de la neología espontánea y de la neología planificada", in CABRÉ María Teresa, FrEIXA Judit and SolÉ Elisabet (Eds.), Lèxic i neologia, Barcelona, Universitat Pompeu Fabra, Institut Universitari de Lingüística Aplicada, Observatori de Neologia, 2002: 159-201.

CARDona Giorgio Raimondo, Diccionario de lingüística, Barcelona: Ariel, 1991.

CASAS Gómez Miguel, La interdicción lingüística. Mecanismos del eufemismo y disfemismo, Cádiz: Universidad de Cádiz, 1986a.

CASAS Gomez Miguel, “L'euphémisme et la théorie du champ morpho-sémantique”, Cahiers de Lexicologie, Vol. 49.2, 1986b: 35-51.

CaSAS GómEz Miguel, “A propósito del concepto lingüístico de eufemismo como sincretismo léxico: su relación con la sinonimia y la homonimia”, Iberoromania, Vol. 37, 1993: 7090.

CASAS Gómez Miguel, “Sinonimia y eufemismo”, Quaderni di Semantica, Vol. 16.1, 1995: 1746.

CASAS Gómez Miguel, "El poder mágico de la palabra", Trivium. Anuario de Estudios Humanísticos, 8. In memoriam Prof. José Luis Millán Chivite, 1996: 29-52. 
CASAS Gómez Miguel, "Tabú de palabra e interdicción conceptual", in PAMIES BerTrán Antonio and LUQUE DURÁN Juan de Dios (Eds.), Trabajos de lexicografía y fraseología contrastivas, Granada: Método Ediciones, 2000: 79-98.

CASAS GómEz Miguel, "Precisiones conceptuales en el ámbito de la interdicción lingüística”, in SANTos Río Luis, BorRego Nieto Julio, GarcíaSAntos Juan Felipe, GómEZ ASENCIO José Jesús and Prieto de los Mozos Emilio (Eds.), Palabras, norma, discurso. En memoria de Fernando Lázaro Carreter, Salamanca: Ediciones Universidad de Salamanca, 2005: 271-290.

CASAS GómEz Miguel, "Towards a new approach to the linguistic definition of euphemism", Language Sciences, Vol. 31, 2009: 725-739.

CASAS Gómez Miguel, "De una visión léxica y pragmático-discursiva a una dimensión cognitiva en la caracterización extralingüística y lingüística del eufemismo", in HoRAK André and TORRE Mariela de la (Eds.), Estudios pragmático-discursivos sobre el eufemismo. Actes du Colloque International L'euphémisme revisité. Nouvelles perspectives pragmatico-discursives (Université de Berne, 2 et 3 septembre 2010), Frankfurt am Maim : Peter Lang, Studien zur romanischen Sprachwissenschaft und interkulturellen Kommunikation, 2011: en prensa.

CERDÀ Ramón (Coord.), Diccionario de lingüística, Madrid: Anaya, 1986.

Chamizo Domínguez Pedro J., Metáfora y conocimiento, Málaga: Anexos de Analecta Malacitana, 16, 1998.

Chamizo Domínguez Pedro J., "Some theses on euphemisms and dysphemisms", Studia Anglica Resoviensia, Vol. 3, 2005: 9-16.

ChAmizo domínguez Pedro J. and SÁnChEzBEnEdito Francisco, Lo que nunca se aprendió en clase. Eufemismos y disfemismos en el lenguaje erótico inglés, Granada, Comares, 2000.

CRESPo FERNÁNDEZ Eliecer, El eufemismo y el disfemismo. Procesos de manipulación del tabú en el lenguaje literario inglés, Alicante: Universidad de Alicante, 2007.

Deroy Louis, "Néologie et néologismes : essai de typologie générale", La banque des mots, Vol. 1, 1971: 5-12.

DíAz HoRmigo María Tadea, "Aproximación lingüística a la neología léxica”, in MARTín CAMACHO José Carlos and RodRíGUEZ PONCE Ma Isabel (Eds.), Morfología: Investigación, docencia, aplicaciones. Actas del II Encuentro de Morfología: Investigación y Docencia. Cáceres, 5 de mayo de 2006, Cáceres: Servicio de Publicaciones de la Universidad de Extremadura, 2007: 33-54.

Díaz HoRmigo María Tadea, "La investigación lingüística de la neología léxica en España. Estado de la cuestión”, LynX. Panorámica de estudios lingüísticos, Vol. 7, 2008: 5-60. Diccionario de uso del español de América y España. Vox, Barcelona: Spes Editorial, 2002. Diccionario ideológico de la lengua española. Vox, Barcelona: Biblograf, 1995.

Diccionario para la enseñanza de la lengua española. Vox, Barcelona-Alcalá de Henares: Biblograf-Universidad de Alcalá de Henares, 1995.

Diccionario SALAMANCA de la lengua española, Madrid, Santillana-Universidad de Salamanca, 1996.

DRAE = REAL ACADEMIA ESPAÑOLA, Diccionario de la lengua española, Madrid: Espasa-Calpe, 2003, 22a ed. Edición electrónica.

DuboIS Jean et alii (1979): Diccionario de lingüística, Madrid: Alianza, 1979.

EDESo Natalías Verónica, "Revisión del concepto de eufemismo: una propuesta de clasificación", RILI, Vol. VII. 2 (14), 2009: 147-163.

FERNÁNDEZ UlLOA Teresa, "La pragmática o el habla como forma de acción: eufemismos y disfemismos en el habla juvenil”, in VÁZQUEZ ORTA Ignacio and GUILLÉN GALVE Ignacio 
(Coords.), Perspectivas pragmáticas en lingüística aplicada, Zaragoza: Anubar, 1998: 39-47.

FERNÁNDEZ-SEVILLA Julio, Neología y neologismo en español contemporáneo, Granada: Don Quijote, 1982.

GómEz SÁnCHEZ María Elena, El eufemismo político y económico en la prensa diaria: Análisis de ABC y El País (1998). Tesis doctoral inédita, Madrid: Facultad de Ciencias de la Información, Universidad Complutense de Madrid, 2004.

Guerrero Ramos Gloria, Neologismos en el español actual, Madrid: Arco/Libros, 1995.

HATZFELD Helmut (1924): Leitfaden der vergleichende Bedeutungslehre. Versuch einer Zusammenstellung charakteristischen semasiologischen Beispielmaterials aus den bekanntesten Sprachen, München: Hueber.

HoRAK André, L'Euphémisme. Entre tradition rhétorique et perspectives nouvelles, München: LINCOM, 2010.

HowARD P., "Euphemisms", The State of the Language: English Observed, London: Penguin, 1986: 100-118.

KanY Charles E., American-Spanish Euphemisms, Berkeley-Los Angeles: University of California Press, 1960.

KonRaD Hedwig, Étude sur la métaphore, Paris: J. Vrin, 1958.

LÁZARo CARRETER Fernando, Diccionario de términos filológicos, Madrid: Gredos, 1974, 3aㅡ ed., 3므 reimpr. [1953].

LECHADo GaRcía José Manuel, Diccionario de eufemismos y de expresiones eufemísticas del español actual, Madrid: Verbum, 2000.

LEWANDOWSKI Theodor, Diccionario de lingüística, Madrid: Cátedra, 1982.

Maldonado GonzÁlez Concepción (Dir.), Clave. Diccionario de uso del español actual, Madrid: Ediciones SM, 2002, 5. - ed., aumentada y actualizada.

MARTín FERNÁNDEZ María Isabel, "Sobre la utilidad de la pragmática en la clasificación de los eufemismos", Anuario de Estudios Filológicos, Vol. XVII, 1994: 325-337.

MATORE Georges, "Le néologisme : naissance et diffusion", Le français moderne, Vol. 2, 1952: 87-92.

Moliner María, Diccionario de uso del español, 2 vols., Madrid: Gredos, 1998.

MonTERo Emilio, El eufemismo en Galicia (su comparación con otras áreas romances), Santiago de Compostela: Universidad de Santiago de Compostela, 1981.

Moreno Fernández Francisco, Principios de sociolingüística y sociología del lenguaje, Barcelona: Ariel, 1998.

NyRoP Christopher, Grammaire historique de la langue française, IV : La sémantique, Copenhague: Gyldendalske Boghandel Nordisk Forlag, 1913.

Penadés Martínez Inmaculada and Díaz Hormigo María Tadea, "Hacia la noción lingüística de motivación”, in ÁLVAREZ DE LA GRANJA María (Ed.), Lenguaje figurado y motivación. Una perspectiva desde la fraseología, Frankfurt am Main: Peter Lang, 2008: 51-68.

PotTiER-NAVARRo Huguette, "La néologie en espagnol contemporain", Les langues néolatines, Vol. 229-230, 1979:148-172.

REAL ACADEMIA ESPAÑOLA, Diccionario de la lengua española, Madrid: Espasa-Calpe, 2003, 22ª ed. Edición electrónica.

REY Alain, "Le néologisme : un pseudoconcept?", Cahiers de Lexicologie, Vol. 28, 1976: 3-7.

Richards Jack C., Platt John and PlatT Heidi, Diccionario de lingüística aplicada y enseñanza de lenguas, Barcelona: Ariel, 1997.

RoNDEAU Guy, Introduction à la terminologie, Chicoutimi (Québec): Gaëtan Morin, 1984.

SAUVAGE0T Aurélien, "Valeur des néologismes", La banque des mots, Vol. 1, 1971: 29-36. 
SEco Manuel, "La manipulación de las palabras", Boletín del Instituto de Estudios Giennenses, Vol. 180, 2002: 7-18.

SEco Manuel, AndRÉs Olimpia and Ramos Gabino, Diccionario de español actual, 2 vols., Madrid: Aguilar, 1999.

SENABRE Ricardo, "El eufemismo como fenómeno lingüístico", Boletín de la Real Academia Española, Vol. 51, 1971: 175-189.

URía VARELA Javier, Tabú y eufemismo en latín, Amsterdam: A. M. Hakkert-Publisher, 1997.

UllmanN Stephen, Semántica. Introducción a la ciencia del significado, Madrid: Aguilar, 1976.

WARDHAUGH Ronald, An Introduction to Sociolinguistics, Oxford: Blackwell, 1986.

WARREN Beatrice, "What Euphemisms Tell us about the Interpretation of Words", Studia Linguistica, Vol. 46, 2, 1992: 128-172. 